British Journal of Education

Vol.10, Issue 1, pp. 35-48, 2022

Online ISSN: 2054-636X (Online)

Print ISSN: 2054-6351(Print)

\title{
STATUS OF ENTREPRENEURSHIP DEVELOPMENT PROGRAMME, IN POLYTECHNICS IN SOUTH-EAST NIGERIA
}

\author{
Prof. Basil O. Nwosu \\ Department of Business Education \\ Ebonyi State University, Abakaliki, Ebonyi State, Nigeria \\ Dr. Charles A. Ejeka \\ Department of Office Technology \& Management \\ Imo State Polytechnic, Ehime Mbano Campus, Imo State, Nigeria
}

\begin{abstract}
This study was carried out to find out the status of entrepreneurship development programme in polytechnics in South-East Nigeria. The study adopted descriptive survey design. The study was conducted in all the polytechnics in South-East Nigeria. The population of this study comprised all the 390 entrepreneurship lecturers in polytechnics in South-East Nigeria. As a result of the manageable size, the entire population was used. Thus, there was no sampling of respondents. Data were collected for the study through the administration of validated questionnaire on the respondents. The reliability of the instrument was established using Cronbach alpha $(\alpha)$ reliability statistic. The overall reliability coefficient obtained was 0.84 . Three research questions were formulated to guide the study and one null hypothesis was tested at 0.05 level of significance. In analyzing the data collected for the study, mean and standard deviation were used to answer research questions 1-2 while percentage was used to answer research question 3. T-test inferential statistic was used to test the hypothesis at 0.05 level of significance. The findings of the study revealed that the status of curriculum contents was adequate, all teaching methods indicated were applicable. The study further revealed that well equipped training workshop, quality entrepreneurship textbooks, materials for group projects, internet connection, and materials for practical activities were not available for implementing entrepreneurship development programme of polytechnics in South-East Nigeria. The major implication of the findings of the study lies more on the non-availability of most of the physical facilities for implementing entrepreneurship development programme. Therefore, as the students are learning without adequate relevant physical facilities, the graduates after passing through the entrepreneurship development programme may not have the necessary skills and competencies that emanate from such facilities to set up and run their own business enterprises. It was recommended, among others that government should provide institutions with adequate physical facilities for quality entrepreneurship development programme in Polytechnics in the South-east and that Polytechnic authorities should ensure that entrepreneurship educators comply with using the curriculum designed in order to ensure that the objectives of the programme are achieved.
\end{abstract}

KEYWORDS: status, entrepreneurship, development, programme, polytechnics, South-East, Nigeria

ECRTD-UK https://www.eajournals.org/

ULR: https://doi.org/10.37745/bje.2013 


\section{INTRODUCTION}

The relevance of entrepreneurship development programme in polytechnics cannot be overemphasized. It will help to determine whether the goal of entrepreneurship development programme to equip students with skills, knowledge and abilities for self-employment and selfreliance is being achieved or not. Thus, there is need to determine the status of entrepreneurship development programme in polytechnics in South-East Nigeria.The high rate of unemployment among graduates of polytechnics in Nigeria has become a serious challenge to educationists and the government. It has increased the call for curriculum planners and management of polytechnic education to seek effective methods that will train graduates for the world of work and selfreliance. This explains why the Nigerian government stipulated in her National Policy on Education that the acquisition of appropriate skills, abilities and competencies, both mental and physical are pre-requisites for individuals to live in and contribute to the development of the society (Federal Republic of Nigeria (FRN, 2014).

It is in the bid to equip Nigerian graduates with skills and competencies that would enable them become self-reliant upon graduation, that the Federal Ministry of Education directed that entrepreneurship development programme and new venture creation should be included as part of the curricular of polytechnics through the National Board for Technical Education (NBTE) effective from the 2007/2008 academic session (Gabadeen and Raimi, 2012). This is based on the belief that entrepreneurship development programme will help enlighten the youths on how to discover business opportunities, business ideas and act on them promptly in order to harness the opportunity and convert same to profitable venture.

Entrepreneurship development programme is essential not only to shape the mindset of young people but also to provide the skills and knowledge that are central to the development of entrepreneurial culture in the society. It provides students and youth with motivation, knowledge and skill essential to launch successful business ventures. Entrepreneurship development programme prepares youths to be responsible and make individuals who become entrepreneurs or entrepreneurial thinkers by exposing them to real life learning experiences where they will be required to think (Olawale and Kaegon, 2012).

Entrepreneurship development programme, according to Azuka (2016), is a process of teaching learners in a formal setting how to generate business ideas, evaluate alternatives with the aim of converting ideas into opportunities taking into consideration the capabilities of the entrepreneurs, conducting feasibility studies, writing bankable business plans, organizing and managing businesses with passion, creativity and innovation with a vision to making a profit. The author added that the objectives of entrepreneurship development programme include:

a) developing entrepreneurial drive among students (raising awareness and motivation)

b) training students in what is needed to set up a business and to manage its growth 
developing the entrepreneurial spirit and abilities needed to identify and exploit business opportunities.

According to Baba (2013), entrepreneurship is the act of starting a company, arranging business deals and taking risks in order to make profit through the entrepreneurship skills acquired. The entrepreneurship spirit is a pre-requisite to an entrepreneurial society and culture. This spirit is required for the overall economic growth of any nation especially developing ones like Nigeria. This definition is in line with the view of Ojeifo (2013) that entrepreneurship is the willingness and the ability of an individual or a firm or an organization to identify an environmental change and exploit such an opportunity to produce goods and services for public consumption. Development according to Hornby (2014) is the act of improving, by expanding or refining a phenomenon or perhaps a process in which something passes by degrees to a different stage especially a more advanced, matured or beneficial stage. When related to entrepreneurial development programme, it may be deduced that entrepreneurial development is any act or effort made in respect of entrepreneurship for its advancement, maturity and being more beneficial. Thus, the academic and practical interests in the field of entrepreneurial development have gained considerable and serious attention over the years from many scholars.

The aim of entrepreneurship development programme therefore, is to encourage and train recipients to create self-employment opportunities for themselves. Thus, Oduma (2006) noted that entrepreneurship development programme is the key agent in the development of human creative and innovative talents. The stimulation of human business interests and potentials including the development of managerial skills, human relations and appreciable positive altitude needed for the establishment and operation of a new venture on profit basis.

Jeffery in Nwokoli (2016) noted that effective entrepreneurship development programme prepares the recipients to be responsible, and enterprising individuals who become entrepreneurs or entrepreneurial thinkers, contributes to economic development and sustainable communities. Jeffery noted further that it provides opportunities for youths to master competencies related to core entrepreneurial knowledge, skill and attitude including.

(a) Business opportunity recognition

(b) Idea generation and marshalling resources in the face of risk to pursue opportunities.

(c) Venture creation and operation

Creativity and critical thinking

It is expected that the introduction of entrepreneurship development programme in polytechnics will bring the problem of growing unemployment to an end or at least to the bearest minimum as it has done in some developed countries of the world. According to Kulo, Agbogo and Okudarie (2017), more than a decade has passed after the mandatory entrepreneurship development in polytechnics, yet the expected result is not in view. Graduates of polytechnics are still largely seen on the street of the nation searching for paid employment. On yearly basis, polytechnics turn out 
graduates who do not show any interest in entrepreneurship venture. Thus, the unemployment rate has remained continuously on the increase year after year.

\section{Statement of the Problem}

Stakeholders in education have constantly lamented the unfortunate trend in which polytechnics in Nigeria annually turn out graduates who roam the streets daily in search of jobs. They have placed this ugly phenomenon on the door step of a dysfunctional education system that has structurally failed to capture the dynamic nature of education as agent of transformation and catalyst for individual and societal self-reliance. In a positive reaction to this development, the Federal Government in 2007 reviewed the curricular of polytechnics to include entrepreneurship development programme. The target in this innovation is that of wealth creation, employment generation, and poverty reduction and also for value reorientation to be effectively pursued, attained and sustained through an efficient relevant and functional education system. By this, entrepreneurship development programme is designed to stimulate the interest of graduates and equip them with necessary skills and aptitude for self-employment and self-reliance. However, there is a growing concern that more than a decade after the introduction of entrepreneurship development programme policy in polytechnics, graduate unemployment seems to remain unabated. It is becoming more worrisome that entrepreneurship development programme which is widely acclaimed to have helped many nations of the world to reduce unemployment has not made much impact on the Nigerian unemployment situation. This is becoming more worrisome as many polytechnic graduates are still found roaming the streets in search of white collar jobs that are scarcely available. Many students who have undertaken entrepreneurship development programme courses do not appear anywhere near entrepreneurship venture after graduation and so remain unemployed.

This situation is so obvious that one may ask: what could be responsible for the ugly situation? Could it be due to the curriculum contents of entrepreneurship development programme students were exposed to or teaching and evaluation methods adopted by entrepreneurship educators in polytechnics? Could it be linked to the physical facilities used by entrepreneurship educators in polytechnics? These questions constitute the worry of this study.

\section{Purpose of the Study}

The purpose of the study was to ascertain the status of entrepreneurship development programme in polytechnics in South-east Nigeria. Specifically, the study sought to ascertain the status of:

1. curriculum contents of entrepreneurship development programme in polytechnics in South-east Nigeria

2. teaching methods used for entrepreneurship development programme in polytechnics in South-east Nigeria

3. physical facilities available for use in entrepreneurship development programme in polytechnics in South-east Nigeria

\section{Research Questions}

The study was guided by the following research questions: 
1. What is the status of curriculum contents of entrepreneurship development programme in polytechnics in South-east Nigeria?

2. What is the status of teaching methods used for entrepreneurship development programme in polytechnics in South-east Nigeria?

3. What is the status of physical facilities used for entrepreneurship development programme in polytechnics in South-east Nigeria?

\section{Hypothesis}

The following null hypothesis was tested at 0.05 level of significance.

Ho: There is no significant difference between the mean ratings of male and female entrepreneurship educators on the status of entrepreneurship development programme in polytechnics in South-east Nigeria.

\section{METHODS}

This study utilized descriptive survey research design. The study was conducted in South-east geopolitical zone of Nigeria, which comprises Abia, Anambra, Ebonyi, Enugu and Imo States. Southeastern Nigeria is one of the six geopolitical zones in Nigeria mainly occupied by Igbo speaking Nigerians. The population of this study comprised all the entrepreneurship lecturers in polytechnics in South-east Nigeria. The population of the study was made up of 390 entrepreneurship educators in polytechnics in South-east Nigeria, comprising both males and females with varied years of teaching experiences. Data concerning the population of the study was obtained from Entrepreneurship Development Centres of the various polytechnics in South-east Nigeria. The entire population was studied since the population size is manageable. Thus, there was no sampling of respondents.

\section{Instrument for Data Collection}

The instrument that was used to elicit data for this study is a structured questionnaire, titled: Status of Entrepreneurship Development Programme Questionnaire (SEDPQ) which was developed by the researchers with insight gained from literature reviewed. The SEDPQ consisted of two parts A and B. Part A focuses on respondents' demographic data such as: gender, and years of teaching experience of lecturers in the polytechnics while Part B is made up of six clusters, B1 to B3, covering the six research questions. The clusters contain items on curriculum content of entrepreneurship development programme, method of teaching entrepreneurship development programme and instructional facilities for entrepreneurship development programme respectively. 
The instrument is structured on a 4-point rating scale with response options as shown below:

\begin{tabular}{|llll|}
\hline Response & Options & \multicolumn{2}{l|}{ Rating } \\
\hline Strongly Agree & (SA) & 4 & points \\
\hline Agree & (A) & 3 & points \\
\hline Disagree & (D) & 2 & points \\
\hline Strongly Disagree & (SD) & 1 & point \\
\hline Available & (A) & & \\
\hline Not Available & (NA) & & \\
\hline
\end{tabular}

Respondents were required to examine the items in clusters B1 - B3 of the questionnaire and then rate to show the level of their agreement or disagreement with the various items of the questionnaire. To ascertain the validity of the instrument for the study, the purpose of the study, research questions, hypothesis and the questionnaire were given to five experts one from Science Education Department and four from Business Education Department, Ebonyi State University, Abakaliki for validation. Their comments and suggestions were incorporated in producing the final copy of the instrument.

After determining the validity of the instrument, it was subjected to internal consistency test using the Cronbach Alpha. The items were tested using 30 lecturers in Entrepreneurial Development programme from polytechnics in the South-South Nigeria. and a general coefficient of 0.84 . This is considered high enough for the instrument to be reliable.Copies of the questionnaire were personally administered on entrepreneurship educators by the researchers with the help of twelve research assistants. These assistants were drawn from members of staff in each of the polytechnics in south-east Nigeria where the entrepreneurship development courses are offered. The use of assistants who are members of staff helped in reaching all the respondents and fast tracking the administration of the questionnaire. The assistants were briefed on the modalities of the administration of the questionnaire. The use of telephone calls, text messages and email assisted the researchers to adequately monitor the activities of research assistants.

\section{METHOD OF DATA ANALYSIS}

Data collected for the study were analyzed using percentage, mean rating, standard deviation, ttest and $\mathrm{X}^{2}$ inferential statistic. The mean statistic and standard deviation were used in answering the research questions $1-2$, while percentage was used to answer research question 3 . Hypothesis was tested using the t-test statistic at 0.05 level of significance. Decision Rule: For research 
question $1-2$, any item with a mean score that is equal to or greater than 2.5 was considered agreed while any item with a mean scores that is less than 2.5 was considered disagreed. For research question 3, any item with a percentage score that is equal to or greater than $50 \%$ was considered available while any item with a percentage score that is less than $50 \%$ was considered not available. With respect to hypotheses, a null hypothesis was accepted where the calculated tvalue or $\mathrm{X}^{2}$ value is less than the critical value and was rejected where the calculated t-value or $\mathrm{X}^{2}$ value was equal to or greater than the critical value at 0.05 level of significance.

\section{Presentation of Data}

The results of the study were presented in tables according to research questions while the test of hypothesis was presented in table 4.

\section{Research Question 1}

What is the status of curriculum contents of entrepreneurship development programme in polytechnics in South-east Nigeria?

The summary of the analysis of data relating to this research question is presented in Table 1.

Table 1: Mean Result on Status of Curriculum Contents of Entrepreneurship Development Programme

\begin{tabular}{|c|c|c|c|c|c|c|c|c|}
\hline $\begin{array}{l}\mathbf{S} / \\
\mathbf{N}\end{array}$ & Item & SA & A & D & SD & $\bar{x}$ & S.D & $\begin{array}{l}\text { Remar } \\
\text { ks }\end{array}$ \\
\hline 1. & There is a uniform curriculum used in all the polytechnics. & 90 & 155 & 67 & 76 & 2.66 & 1.03 & Agreed \\
\hline 2. & The curriculum is standard. & 136 & 154 & 69 & 29 & 3.02 & 0.91 & Agreed \\
\hline 3. & The curriculum has clear and specific statement of purpose. & 254 & 86 & 16 & 32 & 3.44 & 0.90 & Agreed \\
\hline 4. & The curriculum is dynamic. & 254 & 86 & 16 & 32 & 3.44 & 0.90 & Agreed \\
\hline 5. & Every aspect of the curriculum has clear objectives. & 185 & 86 & 16 & 101 & 2.91 & 1.24 & Agreed \\
\hline 6. & Every aspect of the curriculum has end goals to achieve. & 109 & 127 & 70 & 82 & 2.67 & 1.09 & Agreed \\
\hline 7. & The curriculum is flexible. & 208 & 67 & 60 & 53 & 3.10 & 1.10 & Agreed \\
\hline 8. & $\begin{array}{l}\text { It provides sufficient scope for the cultivation of unique } \\
\text { skills. }\end{array}$ & 120 & 70 & 98 & 100 & 2.54 & 1.17 & Agreed \\
\hline 9. & $\begin{array}{l}\text { The curriculum provides for personality development of the } \\
\text { students/learners }\end{array}$ & 171 & 74 & 39 & 104 & 2.80 & 1.25 & Agreed \\
\hline 10. & $\begin{array}{l}\text { It covers contents that enable students to come up with new } \\
\text { ideas. }\end{array}$ & 250 & 86 & 18 & 34 & 3.42 & 0.93 & Agreed \\
\hline 11. & $\begin{array}{l}\text { The curriculum equips the students with risk taking } \\
\text { competencies. }\end{array}$ & 149 & 90 & 39 & 110 & 2.71 & 1.24 & Agreed \\
\hline 12. & $\begin{array}{l}\text { It equips students with management competencies for } \\
\text { business success. }\end{array}$ & 247 & 90 & 19 & 32 & 3.42 & 0.91 & Agreed \\
\hline 13. & $\begin{array}{l}\text { It provides students with ability to budget and forecast } \\
\text { business growth. }\end{array}$ & 201 & 59 & 92 & 36 & 3.09 & 1.05 & Agreed \\
\hline 14. & $\begin{array}{l}\text { The curriculum is design to enable students to set personal } \\
\text { goals. }\end{array}$ & 183 & 44 & 93 & 68 & 2.88 & 1.18 & Agreed \\
\hline $1 J$. & $\begin{array}{l}\text { time. } \\
\text { time }\end{array}$ & 76 & 99 & 90 & 123 & 2.33 & 1.11 & $\begin{array}{l}\text { Disagre } \\
\text { ed }\end{array}$ \\
\hline
\end{tabular}


British Journal of Education

Vol.10, Issue 1, pp. 35-48, 2022

Online ISSN: 2054-636X (Online)

Print ISSN: 2054-6351(Print)

16. It equips students with ability to adapt themselves with the dynamics of business environment.

17. The curriculum exposes students to separate personal expenditure from that of the business.

18. It exposes students to the rudiments for preparing simple budgets.

19.. It equips students to recognize business opportunities.

20. It equips students to set appropriate business goals.

277 240

$41 \quad 24$

$\begin{array}{lll}46 & 3.41 & 1.04\end{array}$

Agreed

27

9

$96 \quad 17$

$\begin{array}{lll}35 & 3.39 & 0.93\end{array}$

Agreed

166

$\begin{array}{ll}73 & 54\end{array}$

$34 \quad 3.39$

1.02

Agreed

190

8279

$\begin{array}{ll}61 & 2.91\end{array}$

1.12

$90 \quad 44$

643.0

1.12

Agreed

21. The curriculum provides students with ability to suitably organize resources.

22. The curriculum takes into account relevant theories of learning.

147

$44 \quad 123$

$74 \quad 2.68 \quad 1.16$

Agreed

23. The curriculum provides students with ability to suitably mobilize group for high performance.

The curriculum is such that it makes room for monitoring.

Grand Mean

$\begin{array}{lllllll}199 & 23 & 76 & 90 & 2.85 & 1.27 & \text { Agreed }\end{array}$

$\begin{array}{lllllll}187 & 101 & 57 & 43 & 3.11 & 1.03 & \text { Agreed }\end{array}$

3.01 Agreed

Table 1 presents the result on the rating of entrepreneurship educators on the status of curriculum contents of entrepreneurship development programme in polytechnics in South-East Nigeria. According to the results, items 1, 2, 3, 4, 5, 6, 7, 8, 9, 10, 11, 12, 13, 14, 16, 17, 18, 19, 20 21, 22, 23 and 24 received mean scores above 2.50 . This implies that the respondents agreed that the entrepreneurship development curriculum contents in polytechnics are adequate. Only item 15 (entrepreneurship curriculum cntents equip students with ability to stay positive in challenging time) received mean rating (2.33) less than 2.50 hence was considered inadequate. However, the grand mean of the cluster is 3.01 which is above 2.50. Therefore, it was adjudged that the curriculum contents of entrepreneurship development programme of polytechnics in South-east Nigeria are adequate.

\section{Research Question 2}

What is the status of the teaching methods used for entrepreneurship development programme in polytechnics in South-east Nigeria?

The summary of the analysis of data relating to this research question is presented in Table 2. 
British Journal of Education

Vol.10, Issue 1, pp. 35-48, 2022

Online ISSN: 2054-636X (Online)

Print ISSN: 2054-6351(Print)

Table 2: Mean Result on Status of Methods of Teaching Entrepreneurship Development Programme

\begin{tabular}{|c|c|c|c|c|c|c|c|c|}
\hline $\mathbf{S} / \mathbf{N}$ & Item & SA & $\mathbf{A}$ & $\mathbf{D}$ & SD & $\bar{x}$ & S.D & Remarks \\
\hline 41. & Lecture method. & 91 & 124 & 91 & 82 & 2.57 & 1.06 & Agreed \\
\hline 42. & Games method. & 124 & 135 & 76 & 53 & 2.85 & 1.02 & Agreed \\
\hline 43. & Design based method. & 144 & 80 & 33 & 131 & 2.61 & 1.28 & Agreed \\
\hline 44. & Case study method. & 172 & 75 & 46 & 95 & 2.83 & 1.23 & Agreed \\
\hline 45. & Group discussion method. & 197 & 74 & 69 & 48 & 3.08 & 1.08 & Agreed \\
\hline 46. & Individual project report. & 151 & 78 & 79 & 89 & 2.75 & 1.19 & Agreed \\
\hline 47. & Cooperative learning method. & 151 & 107 & 63 & 67 & 2.88 & 1.11 & Agreed \\
\hline 48. & Group project. & 96 & 100 & 94 & 98 & 2.50 & 1.11 & Agreed \\
\hline 49. & Guest speaker. & 101 & 111 & 106 & 70 & 2.62 & 1.05 & Agreed \\
\hline 50. & Resource person method. & 177 & 102 & 58 & 51 & 3.04 & 1.06 & Agreed \\
\hline 51. & Problem solving. & 132 & 121 & 50 & 85 & 2.77 & 1.13 & Agreed \\
\hline 52. & Critical thinking method. & 111 & 131 & 83 & 63 & 2.74 & 1.04 & Agreed \\
\hline 53. & Web-based teaching method. & 199 & 98 & 48 & 43 & 3.16 & 1.02 & Agreed \\
\hline 54. & Take home assignment method. & 188 & 73 & 42 & 85 & 2.93 & 1.21 & Agreed \\
\hline 55. & Simulation method. & 167 & 106 & 59 & 47 & 3.05 & 1.04 & Agreed \\
\hline \multirow[t]{2}{*}{56.} & Field trip. & 180 & 80 & 65 & 63 & 2.97 & 1.13 & Agreed \\
\hline & Grand Mean & & & & & 2.83 & & Agreed \\
\hline
\end{tabular}

Table 2 shows the rating of entrepreneurship educators on the methods used in teaching entrepreneurship development programme in polytechnics in South-East Nigeria. The result reveals that all the 16 items $(41,42,43,44,45,46,47,48,49,50,51,52,53,54,55$ and 56) on methods of teaching entrepreneurship development programme received mean scores above 2.50. The grand mean of this cluster (2.83) is also above 2.50. This implies that the respondents agreed that all the above teaching methods are used in teaching entrepreneurship development programme in polytechnics in South-East Nigeria.

\section{Research Question 3}

What is the status of physical facilities used for entrepreneurship development programme in polytechnics in South-east Nigeria?

The summary of the analysis of data relating to this research question is presented in Table 6 
Print ISSN: 2054-6351(Print)

\begin{tabular}{|c|c|c|c|c|c|}
\hline $\mathbf{S} / \mathbf{N}$ & Item & $\begin{array}{l}\text { No } \\
\text { Available }\end{array}$ & $\begin{array}{l}\text { Percentage } \\
\text { Available }\end{array}$ & $\begin{array}{l}\text { No Not } \\
\text { Available }\end{array}$ & $\begin{array}{l}\text { Percentage Not } \\
\text { Available }\end{array}$ \\
\hline 85. & Equipped practical training workshop. & 127 & 33.02 & 261 & 66.78 \\
\hline 86. & Computer. & 388 & 100 & 0 & 0 \\
\hline 87. & ICT facilities. (E.g. Scanner, Printers, Photocopiers) & & & & \\
\hline & & 300 & 78 & 88 & 22 \\
\hline 88. & Adequate lecture halls. & 281 & 73.06 & 107 & 26.94 \\
\hline 89. & Spacious lecture rooms. & 302 & 78.52 & 86 & 21.48 \\
\hline 90. & Quality text books. & 96 & 24.96 & 292 & 75.04 \\
\hline 91. & Instructional materials. & 388 & 100 & 0 & 0 \\
\hline 92. & $\begin{array}{l}\text { Materials for group projects. (E.g. Assembling of } \\
\text { computers) }\end{array}$ & 192 & 47.92 & 206 & 50.08 \\
\hline 93. & Internet connection for web based learning. & 88 & 22.88 & 300 & 77.12 \\
\hline 94. & White marker board. & 388 & 100 & 0 & 0 \\
\hline 95. & Materials for practical.(E.g. Typing sheets) & 129 & 33.54 & 259 & 66.46 \\
\hline
\end{tabular}

Table 3 shows the percentage of availability of physical facilities for entrepreneurship development programme in polytechnics in South-east Nigeria. The table reveals that item 86 (computer), item 91 (instructional materials) and item 94 (white marker boards) recorded 100\% availability. The table also revealed that item 87 (other ICT facilities like scanner, photocopiers, printers), item 88 (adequate lecture halls) and item 89 (spacious lecture rooms) also recorded percentage availability above $50 \%$. However, the table revealed that item 85 (well equipped training workshop), item 90 (quality entrepreneurship textbooks), item 92 (materials for group projects), item 93 (internet connection) and item 95 (materials for practical activities) recorded percentage availability of less than $50 \%$.

\section{Testing of Hypothesis:}

The null hypothesis formulated for this study was tested. The t-test statistic was used for testing Hypothesis at 0.05 level of significance.

Ho1: There is no significant difference between the mean ratings of male and female entrepreneurship educators on the status of entrepreneurship development programme in polytechnics in South-east Nigeria.

Table 4: t-test Results on Status of entrepreneurship educators of entrepreneurship development programme in polytechnics in South-east Based on Gender

\begin{tabular}{llllllllll}
\hline S/N & Var. & No & $\bar{x}$ & S.D & df & t-cal & t-crit & Decision & Significance \\
\hline & Male & 223 & 3.08 & 1.03 & & & & & \\
& Female & 165 & 2.92 & 1.08 & 386 & 4.074 & 1.96 & Reject HO & Significant
\end{tabular}

Table 4 shows the t-test analysis of responses of male and female entrepreneurship educators on the status of entrepreneurship development programme in polytechnics in South-east Nigeria. The table also revealed that the overall $\mathrm{t}$-calculated value of 4.07 is greater than the $t$-critical value of 1.96 at 386 degree of freedom at 0.05 level of significance. Therefore, Ho was rejected. This 
means that there is a significant difference between the mean ratings of male and female entrepreneurship educators on the status of curriculum contents of entrepreneurship development programme in polytechnics in South-east Nigeria.

\section{DISCUSSION OF FINDINGS}

The findings of the study revealed that the curriculum contents of entrepreneurship development programme of polytechnics in South-east Nigeria are adequate. In the opinion of respondents, the curriculum contents are adequate in the sense that there is uniform entrepreneurship curriculum used in all the polytechnics, the curriculum is standard; the curriculum is dynamic and has clear and specific purposes. The study also revealed that the curriculum is flexible; provide sufficient scope for the cultivation of unique skills; provides for personality development of students and learners. Furthermore, the study revealed that entrepreneurship development curriculum contents are adequate in the sense that it was design to enable students to set personal goals; equips students with ability to stay positive in challenging time; equips them with ability to adapt themselves with the dynamics of business environment; exposes students to separate personal expenditure from that of the business and exposes students to the rudiments for preparing simple budgets. The study further revealed that the contents of the curriculum help students to recognize business opportunities; set appropriate business goals and provides students with ability to suitably organize resources.

These findings are in accordance with Nedum-Ogbede (2017) who observed that for the entrepreneurial curriculum contents to attain the set goals, the objectives of employment generation is a sine-qua-non if the course objective is to be attained. Similarly, Nwosu and Amahi (2019) observed that curriculum which seems not to be comprehensive and not capable of imparting positively the relevant skills in students to build their capabilities will produce ill equipped graduates. In other words, comprehensive curriculum contents will ensure that competent and qualified graduates are produced.

The findings of the study with respect to the tested hypothesis on table 4 indicated that there is a significant difference between the mean ratings of male and female entrepreneurship educators on the status of curriculum contents of entrepreneurship development programme in polytechnics in South-east Nigeria. This means that there is no consensus among the respondents in terms of gender on the status of curriculum contents of entrepreneurship development programme in polytechnics in South-east Nigeria.

Table 2 reveals the rating of entrepreneurship educators on the methods used in teaching entrepreneurship development programme in polytechnics in South-east Nigeria. The findings of the study revealed that entrepreneurship educators in polytechnics in South-east Nigeria use lecture method, games method, design based method, case study method, group discussion method and cooperative learning method. The study also showed that group project, guest speaker, resource person method, problem solving, critical thinking method, web-based teaching method and take 
home are used by entrepreneurship educators in teaching entrepreneurship development in polytechnics in South-east Nigeria.

The result of the study is in accordance with the study of Oduma (2012) which revealed that lecturers of entrepreneurship education often use lecture method, individual project method, guest trainers to teach entrepreneurship education. Similarly Onyesom (2017) noted that method is very vital in any teaching/learning situation because the method adopted by the teacher may promote or hinder learning. It may sharpen mental activities which are the basis of social power, or it may discourage initiatives and curiosity thus making self-reliance and survival difficult. Teaching and learning process in entrepreneurship development that will ensure proper acquisition of entrepreneurial skill must be somewhat interactive to achieve optimal result. In other words, no teaching and learning process can be effective unless it is interactive (Onyesom, 2017). The findings of the study with respect to the tested hypothesis on Table 4 indicated that there is a significant difference between the mean ratings of male and female entrepreneurship educators on the status of methods of teaching in entrepreneurship development programme in polytechnics in South-east Nigeria. This implies that there is no consensus among the respondents in terms of gender on the status of methods of teaching in entrepreneurship development programme in polytechnics in South-east Nigeria. Ekwe, Udemba and Ojuro (2019) agreed that the quality of teachers and the utilization of the right teaching method play significant role in students' acquisition of entrepreneurial and employability skills.

The analysis of data in Table 3 shows the percentage availability of facilities for entrepreneurship development programme in polytechnics in South-east Nigeria. The table revealed that computer, instructional materials and white marker boards are available for implementing entrepreneurship development programme of polytechnic in South-east Nigeria. The study also revealed that other ICT facilities like scanner, photocopiers, printers etc., lecture halls and spacious lecture rooms have availability percentage above $50 \%$. However, the study revealed that well equipped training workshop, quality entrepreneurship textbooks, materials for group projects, internet connection, and materials for practical activities were not adequately provided for implementation of entrepreneurship development programme of polytechnics in South-east Nigeria.

The findings of this study agreed with that of Ani (2016) who held that that material resources such as spacious classroom, equipped practical training workshop, instructional materials, interconnection for web based learning, seat for students, tables and chairs and continuous assessment materials were highly available for teaching entrepreneurship education in tertiary institution. In the words of Akwara and Baba (2019), availability of infrastructures and facilities in the right quantity and quality is germane in education provision because lack or inadequacy of them will make environment uncomfortable for students to learn and to effectively teach entrepreneurship education. 


\section{CONCLUSION}

Based on the findings of the study, it was therefore concluded that curriculum contents of entrepreneurship development programme of polytechnics are adequate and that entrepreneurship educators in polytechnics in South-east Nigeria use lecture method, games method, design based method, case study method, group discussion method and cooperative learning method.

\section{Recommendations}

Based on the findings and conclusion of the study, the following recommendations were made:

1. Government should provide polytechnics with adequate physical facilities for quality entrepreneurship development programme in polytechnics. Instructional facilities constitute an indispensable and cardinal requirement for effective teaching because they enhance the effectiveness of the techniques, methods or strategies of teaching and learning especially in entrepreneurship development that involves a lot of practical exercises.

2. Since the curriculum contents are found to be adequate for competent entrepreneurial development of students, polytechnic authorities should ensure that lecturers comply with using the curriculum designed in order to ensure that the objectives of the programme are achieved. This is because no matter the instruction contents built into the curriculum it is the educators that will drive it into fulfillment.

3. Lecturers of entrepreneurship development programme should continue to use the various teaching methods revealed in this work while further efforts should be made to research on other methods that are not included in the option which will also reduce unemployment among the youth. 4. Polytechnics in other geo-political zones in Nigeria should ensure that various findings of the study are adopted in their institutions for competent entrepreneurial development of students especially with respect to domiciliation, methods used in teaching and adequacy of human resources for entrepreneurship development programme.

\section{References}

Ain, B. (2016). Status of entrepreneurship education programme in tertiary institutions in Edo State. Unpublished Doctoral Thesis. Ebonyi State University, Abakaliki.

Akwara, N. F. \& Baba, E. I. (2019). Repositioning entrepreneurship education for national development in a period of economic meltdown. Association of Business Educators of Nigeria Conference Proceedings 6(1), 331 - 337.

Azuka, E. B. (2016). Entrepreneurship education in Nigeria: Issues, challenges and strategies. Nigerian Journal of Business Education 4(2), $1-11$.

Baba, G. K. (2013). The challenges of entrepreneurship development in Nigeria and way forward, Journal of Business and Organizational Development, 5(1), 54-64.

Ejeka, C. A (2021). Status of entrepreneurship development programme in polytechnics in Southeast Nigeria. Unpulished Doctoral Thesis. Ebonyi State University, Abakaliki.

Ekwe, K. C., Udemba, N. F. \& Ojuro, C. (2019). Strategies for improving employability skill acquisition of business education skills. Nigerian Journal of Business Education 6 (1), 94 $-106$ 
British Journal of Education

Vol.10, Issue 1, pp. 35-48, 2022

Online ISSN: 2054-636X (Online)

Print ISSN: 2054-6351(Print)

Federal Republic of Nigeria (FRN, 2014). National Policy on education. Lagos: NERDC Press.

Hornby, A. S. (2014). Oxford advanced learner's dictionary of current English. Oxford: Oxford University Press.

Kulo, V. A., Agbogo, R. A. \& Okudarie, J.U. (2017). Challenges of entrepreneurship education in Nigeria. Nigerian Journal of Business Education 4(1), 46 - 52.

National Board for Technical Education (2007). Entrepreneurship education curriculum and course specification. Kaduna: Hamitle Consult Nigeria Ltd.

Nedum-Ogbede, P. O. (2017). Implementation of entrepreneurship education curriculum content towards unemployment reduction among universities graduates in Anambra State. Nigerian Journal of Business Education 4(1), 83 - 91.

Nwokoli, N. R. (2016). Small medium scale enterprise managers' rating of entrepreneurial skills needed for business success in Delta State. Unpublished Master's Degree Thesis, Nnamdi Azikiwe University Awka.

Nwosu, B. O. \& Amahi, F. U. (2019). Building the capacity of students of business education with accounting software skills for improved service delivery in modern office and school environments. Nigerian Journal of Business Education 6 (2), 368381

Oduma, C. A. (2006). Towards improving the employability competence of business education graduates in the information and communication technology era. Journal of Information, Communication and Computing Technologies, 2(1), 101-105.

Oduma, C. A. (2012). Fundamentals of Entrepreneurial Education. Abakaliki: Citizens Advocate Publishers.

Ojeifo, S. A. (2013). Entrepreneurship education in Nigeria: A panacea for youth unemployment. Journal of Education and Practice, 4(6), 61-67.

Onyesom, M. (2017). Efficacy of strategies for teaching entrepreneurship education in Delta State. Nigerian Journal of Business Education, 4(1), 1 - 9. 